\title{
The Application of Problem-Based Learning Strategy to Increase High Order Thinking Skills of Senior Vocational School Students
}

\author{
Edy Suprapto ${ }^{1}$, Fahrizal $^{1}$, Priyono $^{1} \&$ Basri K. $^{1}$ \\ ${ }^{1}$ Mechanical Engineering Education, Nusa Cendana University, Kupang, Indonesia \\ Correspondence: Edy Suprapto, Nanga Jamal Street No. 2A, Kupang, NTT, Indonesia. Tel: 62-823-3474-0312. \\ E-mail: edysuprapto93@yahoo.co.id
}

Received: October 19, 2016

Accepted: January 10, 2017 Online Published: May 29, 2017

doi:10.5539/ies.v10n6p123

URL: https://doi.org/10.5539/ies.v10n6p123

\begin{abstract}
This research is to apply and develop a strategy of problem-based learning to increase the ability of higher order thinking skills of senior vocational schools students. The research was done due to a fact that the quality of outputs of the senior vocational schools has not met the competency needed by the stakeholders in the field, that has made the outputs difficult to get jobs, or fail to run a private business of their own. This research is a quasi experiment applying Nonequivalent Control Group Design, done at X TKR 1 class of 38 students and X TKR 2 class of 38 students of Senior Vocational School II, Kupang, NTT Province, Indonesia. The normality and homogeneity of tests were done to obtain the test of analysis requirement. T-test was done to analyze the data obtained. The results show that: (1) the use of problem-based learning strategy is superior to the conventional study; (2) the application of problem-based learning strategies capable of improving high order thinking skills of students, which is implemented in problem solving skills, teamwork, and self-confidence better. (3) in the future, the high order thinking skills will be very important in winning the job competition, find solutions to problems in the workplace and establish good cooperation with others, so it will support the success of their careers in the future.
\end{abstract}

Keywords: problem-based learning strategy, high order thinking skills

\section{Introduction}

In a learning process, it is expected that a learner is able to increase his cognitive, affective, and skill competences to prepare himself to be able to run his future life in the society. However, it is a fact that the quality of learning result does not meet yet the competence needed, particularly the outputs of Senior Vocational School II . The lowness of the quality is also acknowledged by Semiawan (2000), where learning emphasizes more on describing facts, knowledge and laws, and on memorization, not on relating emipirical experiences in the real life. Then, Zamroni (2000) and Sumarna (2004) contend that students' weakness in applying knowledge is caused by a tendency that the learning in the classroom does not relate the learning content with the daily life. Further, Waras (2003) has proved that output of senior high school outputs are more accepted by the stakeholders compared with those of senior vocational schools. One reason is that the senior vocational school outputs are less able to apply high order thinking skills compared with those of senior high schools. The same fact is also shown by Nuh (2011) that the work productivity of senior vocational school outputs are still low. The expectation, that senior vocational school outputs are new generations of private businessmen to open new job fields, which is also the main aim of the education in senior vocational schools, has not met yet. To increase the quality of vocational school outputs, adding one more year for practice in Industries or in Politechniques is needed to be well prepared before they come to the fieldwork.

The insufficiency capability of the senior vocational school outputs needs learning process reorientation. In this case, the perspective of student-centered not teacher-centered learning must be highlighted and implemented in the teaching proces. The students are given more opportunity to perform activities covering minds-on activities or hand-on activities. So, the strategy applied in learning engineering must be the one that creates comprehensive learning system, motivates inisiative and responsibility, develops investigation habit for rich and meaningful information or knowledge, and shows dynamic activities in high order thinking process, which is a quality indicator in the problem-based learning strategy (Owens \& Smith, 2000).

So, this research sets forwards and concentrates on how problem-based learning strategy is implemented to 
increase high order thinking skills of the senior vocational school students that leads to increase work competition in the field in the future. This is based on the opinion that, the strategy is capable to overcome learning problem that causes low quality of senior vocational school outputs. The strategy is an active progressive learning approach and student-centered. It is based on real problematic world for the learning process to develop the students' own knowledge, the inquiry, and high order thinking skills.

\section{Materials}

\subsection{Problem-Based Learning Strategy}

In the problem-based learning strategy, the students are involved in a sequence of investigation activities to solve problems by integrating skills and concepts of content of the teaching materials. This is going with the idea of Arends (2008) stating that the problem-based learning places the students in position of solving authentic problems in order to order or arrange the students' own knowledge, develop inquiry and high order thinking skills, and develop self-confidence.

Then, Silver et al. (2004) says that problem-based learning is an active, progressive, and student-centered learning approach, where unstructured problems (from the real world or simulated) are used a initial start of learning. Further, Kelly and Kelam (2009) state that in problem-based learning that is related with real world can increase the students' high order thinking skills towards various problems faced, in order to make the students easy to adapt with future work. The application of problem-based learning can increase the senior vocational school students' high order thinking skills. Further the problem-based learning strategy in this research is applied by adapting with the syntax of Arends (2008)

\subsection{High Order Thinking Skills}

The high order thinking skills is a thinking activity involving the high hierarchy cognitive level of Bloom Taxonoy. Hierarchically, Bloom taxonomy consists of six levels: recall, understand learned facts, apply what has been learned to new situations, analysis ("take apart" information to examine different parts), synthesis (create or invent something; bring together more than one idea), and evaluation (consider evidence to support conclusions).

Further, Anderson and Krathwohl (2001) revise the Bloom taxonomy as the following: remembering, understanding, applying, analyzing, evaluating, and creating. The revision is found easier for many scientists to understand and accept it to be referred in learning theory development. This research for example uses taxonomy of Bloom as the main theoretical reference. In its development, remembering, understanding, applying are categorized as low order thinking skills. So, the high order thinking skills is a result of cognitive learning at the level of analysis learning result, evaluation, and creating.

\section{Method}

\subsection{Research Design}

This research is a quasi experiment applying Nonequivalent Control Group Design" of Tuckman (1999). It was done in the X TKR 1 class of 40 students and X TKR 2 class of 40 students at the Senior Vocational School 2 (SMK N 2) Kupang, in the academic year of 2015/2016. So, the total number of research subject is 80 . However, after ten learning meetings, four students failed to join on because of two reasons: 1) failing to follow all learning activities because of falling sick, and 2) failing to join posttest.

Table 1. The distribution of research subject based on the learning strategy

\begin{tabular}{lcc}
\hline Learning strategy & Frequency & Percentage (\%) \\
\hline Problem-based learning & 38 & 50.0 \\
Conventional learning & 38 & 50.0 \\
Total & 76 & 100 \\
\hline
\end{tabular}

The treatment applied in the research is a problem-based learning and conventional learning. A lottery technique was done to determine a experiment class (problem-based learning treatment) and control class (conventional learning). The treatment for the experiment class is based on the learning of set of equipments. The implementation of research covered: a) pretest for both, experiment and control classes; b) research process, where experiment group was treated with problem-based learning while control group with conventional learning; c) after eight meetings, a posttest was given to both groups, to get data about high order thinking skills. 


\subsection{Research Instrument}

Research instrument is designed according to the learning topics in syllabus of Motor-Cycle subject, based on which, the indicators of learning results are developed. The indicators are the contents of the test instrument in the form of learnng result blue-print.

To test the validity and reliability, the instrument test is tried out first, to students who have passed Motor-Cycle subject. The product moment correlation and formula of KR20 (Sugiyono, 2011) is used to obtain the validity and reliability coefficient. The test instrument was then used to measure the result of high order thinking skills after the tried out instrument showed its validity and reliability.

\subsection{Data Analysis}

Before the experiment was done, both groups of research subjects presented in the front were given a pretest to have general picture about the initial ability of both groups.

This research uses: 1) normality test of Kolmogrov-Smirnov, and 2) homogeneity test of levene's test to have result of analysis prerequisite test. After the data showed normal and homogenous, the analysis was continued with the descriptive data analysis and t-test analysis, by using SPSS of 16.0 version.

\section{Result}

\subsection{The Description of Pretest Data as High Order Thinking Skills}

Table 2. Result of descriptive analysis of pretest data

\begin{tabular}{lcccc}
\hline Learning Startegy & $\mathrm{N}$ & Mean & Std. Deviation & Std. Error Mean \\
\hline Problem-Based learning & 38 & 39.53 & 6.644 & 1.077 \\
Conventional Learning & 38 & 40.23 & 6.028 & .965 \\
\hline
\end{tabular}

The result of normality test of pretest data by using Kolmogorov-Smirnov test, it is found that the SIG coefficient of problem based learning is 0.130 and the conventional learning is 0.200 , higher than 0.05 . So, both groups of pretest data show normal distribution. Meanwhile, the result of test by using Levene Test shows the SIG coefficient of 0.185 , higher than $0.05(0.185>0.05)$, meaning the pretest data are homogeneous (Santoso, 2004).

From the result of the t-test of two independent samples, it is found that $t$ value $=-0,487$, and the SIG value of learning result of Motor-Cycle subject pretest between the group of problem-based learning and the group of conventional learning is 0.627 ( $>0.05$ ). This shows there is not significat difference betwen the two groups in pretest data, meaning the initial ability of both groups is equal.

\subsection{Data of Posttest Learning Result of High Order Thinking Skills}

\subsubsection{By Using Problem-Based Learning Strategy}

Based on the result of measurement during the research, it was known that the mean of students' learning result was 78.026 with the deviation standard of 9.2925. Then the data distribution of learning result using problem-based strategy is shown by Table 3 below.

Table 3. Students' learning result by applying problem-based learning strategy

\begin{tabular}{lccc}
\hline No & Learning Result & Absolute Freequency & Relative Freequency (\%) \\
\hline 1 & $0-59$ & 0 & 0.00 \\
2 & $60-69$ & 5 & 13.16 \\
3 & $70-79$ & 17 & 44.73 \\
4 & $80-89$ & 10 & 26.32 \\
5 & $90-100$ & 6 & 15.79 \\
& Total & 38 & 100.00 \\
\hline
\end{tabular}

\subsubsection{By Using Conventional Learning Strategy}

Based on the result of measurement during the research, it was known that the mean of students' learning result was 71,487 with the deviation standard of 7.531 . Then, the data distribution of learning result using conventional 
strategy is shown by Table 4 below.

Table 4. Students' learning result by using conventional learning strategy

\begin{tabular}{lccc}
\hline No & Learning Result & Absolute Frequency & Relative Frequency $(\%)$ \\
\hline 1 & $0-59$ & 2 & $5.26 \%$ \\
2 & $60-69$ & 9 & $23.68 \%$ \\
3 & $70-79$ & 22 & $57.90 \%$ \\
4 & $80-89$ & 5 & $13.16 \%$ \\
5 & $90-100$ & 0 & $0.00 \%$ \\
& Total & 38 & $100.00 \%$ \\
\hline
\end{tabular}

\subsection{Result of Data Analysis}

\subsubsection{Result of Test of Analysis Prerequisite}

The result of analysis of Kolmogrov-Smirnov is (SIG) $0.172>0.05$, meaning the data of learning result shows normal distribution, and the homogeneity test is (SIG) $0.06>0.05$, meaning the data of learning result is homogeneous. Since the data show normal distribution and homogenous, the analysis can be continued with t-test statistics.

\subsubsection{Result of Hypothesis Testing}

The result of hypothesis testing is displayed by Table 5 and Table 6 below.

Table 5. The result of descriptive analysis of learning result of high order thinking skills

\begin{tabular}{lccccc}
\hline & Learning Strategy & N & Mean & Std. Deviation & Std. Error Mean \\
\hline Learning & Problem-based learning & 38 & 78.0263 & 9.29250 & 1.50744 \\
result & Conventional learning & 38 & 71.5789 & 7.61092 & 1.23465 \\
\hline
\end{tabular}

Table 6. The analysis of t-test for the data of high order thinking skills

\begin{tabular}{|c|c|c|c|c|c|c|c|c|c|c|}
\hline & & \multicolumn{3}{|c|}{$\begin{array}{c}\text { Levene's Test for } \\
\text { Equality of } \\
\text { Variances }\end{array}$} & \multicolumn{4}{|c|}{ t-test for Equality of Means } & & \\
\hline & & \multirow[t]{2}{*}{$\mathrm{F}$} & \multirow[t]{2}{*}{ Sig. } & \multirow[t]{2}{*}{$\mathrm{t}$} & \multirow[t]{2}{*}{ df } & \multirow{2}{*}{$\begin{array}{c}\text { Sig. } \\
\text { (2-tailed) }\end{array}$} & \multirow{2}{*}{$\begin{array}{c}\text { Mean } \\
\text { Difference }\end{array}$} & \multirow{2}{*}{$\begin{array}{l}\text { Std. Error } \\
\text { Difference }\end{array}$} & \multicolumn{2}{|c|}{$\begin{array}{c}95 \% \text { Confidence Interval } \\
\text { of the Difference }\end{array}$} \\
\hline & & & & & & & & & Lower & Upper \\
\hline \multirow{2}{*}{$\begin{array}{l}\text { Learning } \\
\text { Result }\end{array}$} & $\begin{array}{c}\text { Equal variances } \\
\text { assumed }\end{array}$ & 2.791 & .099 & 3.309 & 74 & .001 & 6.44737 & 1.94853 & 2.56485 & 10.32989 \\
\hline & $\begin{array}{c}\text { Equal variances not } \\
\text { assumed }\end{array}$ & & & 3.309 & 71.235 & .001 & 6.44737 & 1.94853 & 2.56234 & 10.33240 \\
\hline
\end{tabular}

Table 5 shows the result of t-test analysis of both independent samples, that is, the mean of class 38 students treated with problem-based learning treatment is 78,026, and the conventional class of 38 students is 71.578 . Meanwhile, table 6 shows the t-test result of the two independent samples. As it is shown by table 6 , the $t$-value is 3.309, and the $p$ value (Sig 2 tailed) is 0,01 . By using significant level $\alpha=0.05$, it is found that $p$ value (Sig 2 tailed) is $0.01<\alpha(0.05)$. This means that the posttest result between the group of problem-based learning and that of conventional learning shows significant difference at $(\mathrm{p}<0.05)$.

So, the use of problem-based learning strategy in the learnng of Motor-Cycle subject in X TKR 1 class is more superior (better) than that of conventional learning in X TKR 2 class.

\section{Discussion}

The pretest result shows that the mean of learning result of the group treated with problem-based learning strategy is 39.53 ad the $\mathrm{SD}=6.644$. Meanwhile, the mean learning result of the one treated with conventional strategy is 40.23 and the $\mathrm{SD}=6.028$. The normality and homogeneity tests of pretest data is normal and 
homogenous, so the analysis can be continued with the t-test. The result of t-test analysis shows that both groups have equal initial ability. It means that the treatment used to the both groups of research subject treated with different learning strategy are not affected by the initial ability.

The application of problem-based learning (table 3) does not affect to value distribution between $0-59$. The value distribution of the subject taught is more dominant at the score of 70-100. Meanwhile, the application of conventional learning (table 4) still shows $5.26 \%$ of research subjects that score between $0-59$. Then, the scores scatter between 60-89, and there is no research subjects that score between 90-100. Based on the score distribution comparison of the research subjects, the problem-based learning strategy has more superior score distribution.

From the t-test analysis it is found that the t-value is 3,309 and the probability significance is 0.001 . The value of probability significance is $0.001<0.05$. So, the problem-based learning strategy has significant influence towards the learning result of high order thinking skills.

If viewed from the mean score, the cognitive learning result (high order thinking skills) from the group of students to whom the problem-based learning strategy (78.026) is applied is higher than that of the group of students to whom the conventional learning strategy is applied (71.578). This means that the application of the problem-based learning strategy results with better influence towards the achievement of learning result compared with that of conventional learning strategy. Based on the research result, it can also be seen that the problem-based learning strategy can make students motivate to learn more individually or in group to look for the problem solution being discussed. Further, such condition has made problem solution ability of the students increase because the students can directly identify all data relevant with the existing situation, that in the end will make the students increase their own high order thinking skills. Besides, the situation of learning by using problem-based strategy makes the students have high motivation to learn more and finish their assignments on time. So, the learning model applied to a specific learning needs a special care because such kind of learning situation has positive influence towards the students' learning results eventhough of the same teaching materials and facilities.

The problem-based learning is a strategy of contextual learning model having seven main principles that is: (1) constructivism, (2) inquiry, (3) questioning, (4) learning community, (5) modelling, (6) reflection, and (7) authentic assessment. The principles must be implemented in learning process to cause independent learning, meaningful learning, problem-based learning, while applying the high order thinking and integration of other disciplines. This process persuade the students to be more active in discussing the learning topic together with their friends using their own strategy to solve the problem, to share ideas, and to formulate or conclude concepts. The teachers play role only as motivators and facilitators in learning. Besides, the benefit of problem-based learning using group work method will practice the students to develop their thinking capability and inisiative, to increase helping each other in social life, and to cooperate in presenting their group work. By such cooperation, the students are in habit in doing tutor among the same age groups done in turn explaining the materials to other friends. In discussing the problem, the critical and creative students present the way to solve problems related to materials being discussed with high order thinking skills. In relevance with that, Arends (1997) states that the purpose of learning by problem solving strategy is not to give so many information to the students, but to help the students develop their own thinking ability, solve the problem and intelectual skills. Differently from the process of problem-based learning, the conventional learning, has very small probability to increase high order thinking skills, because the problems are sterile from students' environmental condition, and there is only one correct answer. The students only learn the steps of solving problems, but not how to solve the problems. Besides, the evaluation of learning result is done by looking at the process and learning result, in the form of performance assessment, project, portofolio, and written test. Such condition can make possibility for the application of problem-based learning more superior than conventional learning.

The application of problem-based learning strategy in a learning process give positive influence towards the students' learning results. This is in line with the research conducted by Danielson, et al. (2003) stating that, by problem based learning strategy, the ability of students' problem solving can increase because the students are habitually faced with learning problems and their solutions. Further, in their research, Sungur and Tekkaya (2006) stated that the class applying problem-based learning has high intrinsic motivation, influences meaning in doing the job, increases the ability to think critically and creatively, has metacognitive and self regulated learning, if compared with the class applying conventional learning.

The other superiority (excellence) of problem-based learning strategy is that it can positively affect the conceptual development of the students and maintain the misconception of the students at the lowest level 
(Akinoglu \& Tandogan, 2007). Then, in their research, Franz et al. (2007) said that the problem-based learning is a learning strategy which is able to increase the skills in solving problems and high order thinking skills based on the real problem situation. In his researh, Raharso (2007) showed that the learning process by applying problem-based strategy give optimal result if compared with that of conventional learning.

Besides, some factors in problem-based learning that can positively affect higher achievement of learning results are: (1) the use of problem-based learning strategy can accelerate the students' graduation. The reason is the students learn the teaching materials from the real context that can help the students to memorize, (2) the students are more motivated to learn when the students know the relevance of learning with real life in the future, mainly forte students who easily get bored going to school (Smith, 2010). Then, there are some strengths of problem-based learning compared with that of conventional learning as said by Suparman (2013), to mention two of them are the following: (1) the students taugh by applying problem-based learning strategy significantly can write better compared with those taught by applying conventional approach, (2) students with high and low achievement motivation treated with problem-based learning strategy significantly can succeed more highly compared with those treated with conventional learning strategy.

Further, the strength of problem-based learning is influenced by the involvement of the students in learning process. In groups, the students actively involved in the process of problem solving in accordance with context of real world around the students, and the teachers act as motivators and facilitators in such learning process. So, the students will be motivated to look for solution of problems accordance with their experiences, so based on knowledge or capabilities that already exist, students will construct new knowledge based on solving problems that have done. This is in accordance with the findings by Sartiani et al. (2012), concluding that the use of problem-based learning strategy in English writing activity has given six excellences including: (1) increasing the students' involvement in writing activity, (2) increasing students' motivation to actively participate, (3) helping the students in developing writing skill, (4) helping the students in solving problems, (5) making students accustomed to discuss or interact with their friends, and 6) helping students in summarizing and reflecting lessons.

From the description above, it can be concluded that the application of problem-based learning strategy will increase the students' learning results. Besides that, the strategy will increase the habit to work in team, to solve real problem, all of which will increase the students' high order thinking skills. The more important thing is this strategy will grow the habit of lifelong learning of the students. This capability in the future will be very important, in winning the job competition, looking for solutions to problems in the workplace and establish good cooperation with others, so it will support the success of their career in the future.

Therefore it can be recommended to teachers to be able to consider the use of problem-based learning strategies in teaching and learning activities, because it has many advantages

\section{Conclusion}

There is significant difference between group students treated with problem-based learning and that of treated with conventional learning. By using SPSS of version 6.0 it is found that the t-test is 3,309 and the probability SIG value is 0,001 lower than $0,05(0,001<0,05)$. In other words, there is significant difference in high order thinking skills between the students of treated with problem-based learning strategy and the students of treated with conventional learning strategy. The achievement of the group of students treated with problem-based learning strategy (mean 78,026) is more superior compared with that treated with conventional learning strategy $(71,578)$.

The application of problem-based learning strategy capable of improving high order thinking skills of students, which is implemented in problem solving skills, teamwork, and self-confidence better.

In the future, the high order thinking skills will be very important, in winning the job competition, looking for solutions to problems in the workplace and establish good cooperation with others, so it will support the success of their career in the future.

\section{Acknowledgements}

We express our gratitude to the Ministry of Research Technology and Higher Education of the Republic of Indonesia, who have been willing to finance our research with the title: The Application of Problem-Based Learning Strategy to Increase High Order Thinking Skills of Senior Vocational School Students.

\section{References}

Akinoglu, O., \& Tandogan, R. O. (2007). The effect of problem based active learning in science education on 
students' academic achievement, attitude and concept learning. Eurasia Journal of Mathematics, Science and Technology Education, 3(1), 71-81.

Anderson, O. W., \& Krathwohl, D. R. (2001). Taxonomy for learning, teaching, and assessing: A revision of bloom's taxonomy of educational objectives. A Bridged Edition. New York: Addison Wesley Longman, Inc.

Arends, R. I. (1997). Classroom instruction and management. New York: McGrawHill Publisher.

Arends, R. I. (2008). Learning to teach (translated by: P. S. dan Sri Mulyantini S.). Yogyakarta: Pustaka Pelajar.

Danielson, J. A., Bander, H. S., Milss, E. M., Vwermeer, P. J., \& Lockee, B. B. (2003). A tool for helping veterinary lear diagnostic problem solving. Education Technology Research and Development, 51(3), 63-81. https://doi.org/10.1007/BF02504553

Franz, D. P., Hooper, P. F., \& Kritsonis, W. A. (2007). National impact: Creating teacher leaders through the use of problem-based learning. National Forum of Applied Educational Research Journal, 20(3), 1-9.

Kelley, T., \& Kelam, N. (2009). A theoretical framework to guide the re-engineering of technology education. Journal of Technology Education, 20(2), 37-49. https://doi.org/10.21061/jte.v20i2.a.3

Nuh, M. (2011). Preparing students entering the world of work. Newspaper, Jakarta: 18 February 2011 Jakarta.

Owens, T., \& Smith, A. J. (2000). Definition and key elements of contextual teaching and learning.

Raharso, S. (2007). Implementation of problem-based learning in college. Ilmu Pendidikan, 34 (1): 55-61.

Santoso, S. (2004). SPSS statistik multivatiate. Jakarta: PT Elex Media Komputindo.

Satriani, I., Emilia, E., \& Gunawan, M. H. (2012). Contextual teaching and learning approach to teaching writing. Indonesian Journal of Applied Linguistics, 2(1), 10-22. https://doi.org/10.17509/ijal.v2i1.70

Semiawan, C. (2000). Relevance future education curriculum (In Sindhunata). Opening the Future of Our Children. Yogyakarta: Kanisius (pp. 19-31)

Silver, C. E. H., Ellina, C., \& Maria, C. D. (2004). Psychological tools in problem-based learning. Enhancing thinking through problem-based learning approaches. International perspective, Singapore: Thompson Learning.

Smith, B. P. (2010). Instructional strategies in family and consumer sciences: implementing the contextual teaching and learning pedagogical model. Journal of Family and Consumer Sciences Education, 28(1), 23-38.

Sugiyono, (2011). Statistics for research. Bandung: Alfabeta.

Sumarna, S. (2004). Improvement of mathematics education in Indonesia education master plan 2005-2009. Paper presented at the national seminar research, education, and application of science dated August 2, 2004, the cooperation FMIPA UNY, Directorate General of Higher Education, and IMSTEP-JICA.

Sungur, S., \& Tekkaya, C. (2006). Effects of problem based learning and traditional instruction on self regulated learning. The Journal of Educational Research, 99(5), 307-3137.

Suparman, L., Marhaeni, A. A. I. N., \& Dantes, N. (2013). The effect of contextual teaching and learning approach upon students' writing competency for the tenth grade students of SMA N 1 Keruak in the academic year 2012-2013. e-Journal Program Pascasarjana Universitas Pendidikan Ganesha. Study Program of English (Volume 1 Tahun 2013).

Tuckman, B. W. (1999). Conducting educational research (5th ed.). Orlando: EarlMcpeek Publisher.

Waras. (2003). Effect of learning model and learning styles of the academic skills, techniques and problem solving (Dissertation). Malang: Pasca Sarjana Universitas Negeri Malang.

Zamroni. (2000). Paradigm education of future. Yogyakarta: Bigraf Publising.

\section{Copyrights}

Copyright for this article is retained by the author(s), with first publication rights granted to the journal.

This is an open-access article distributed under the terms and conditions of the Creative Commons Attribution license (http://creativecommons.org/licenses/by/4.0/). 